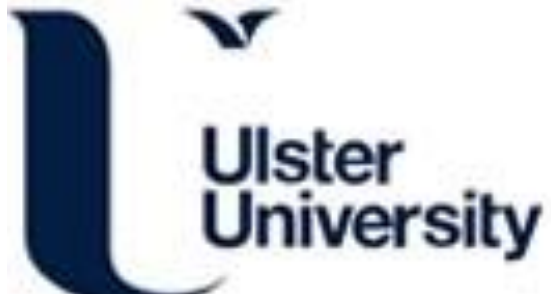

\section{RAD51-UTR haplotype genetic polymorphisms and susceptibility to breast cancer in women from Jordanian population}

Tambuwala, M., \& Bakshi, H. (2021). RAD51-UTR haplotype genetic polymorphisms and susceptibility to breast cancer in women from Jordanian population. Experimental Oncology, 43(2), 149-154.

https://doi.org/10.32471/exp-oncology.2312-8852.vol-43-no-2.16338

Link to publication record in Ulster University Research Portal

\section{Published in:}

Experimental Oncology

Publication Status:

Published (in print/issue): 30/06/2021

DOI:

10.32471/exp-oncology.2312-8852.vol-43-no-2.16338

\section{Document Version}

Publisher's PDF, also known as Version of record

\section{General rights}

Copyright for the publications made accessible via Ulster University's Research Portal is retained by the author(s) and / or other copyright owners and it is a condition of accessing these publications that users recognise and abide by the legal requirements associated with these rights.

\section{Take down policy}

The Research Portal is Ulster University's institutional repository that provides access to Ulster's research outputs. Every effort has been made to ensure that content in the Research Portal does not infringe any person's rights, or applicable UK laws. If you discover content in the Research Portal that you believe breaches copyright or violates any law, please contact pure-support@ulster.ac.uk. 


\title{
RAD51-UTR HAPLOTYPE GENETIC POLYMORPHISMS AND SUSCEPTIBILITY TO BREAST CANCER IN WOMEN FROM JORDANIAN POPULATION
}

\author{
M.S. Al Zoubi ", ", L.N. AL-Eitan', D.M. Rababa'h', K. Al-Batayneh', R. Farzand ${ }^{3}$, G.A. Quinn', \\ M.M. Tambuwala ${ }^{4}$ H.A. Bakshit, * \\ ${ }^{1}$ Yarmouk University, Irbid 21163, Jordan \\ ${ }^{2}$ Jordan University of Science and Technology, Irbid 22110, Jordan \\ ${ }^{3}$ University of Huddersfield, Queensgate, HD12ZD, UK \\ ${ }^{4}$ Ulster University, Coleraine, BT52 1SA, UK
}

Background: Genetic predisposition to breast cancer (BC) has been extensively explored to achieve an enhanced understanding of the biology of $\mathrm{BC}$. Targeting candidate genes to screen different genetic variants such as RAD51 gene that plays a critical role in DNA repair pathways including the double-strand break repair system is an important task. Aim: To study several single nucleotide polymorphisms (SNPs) within RAD51-UTR gene and to find their relationship with BC risk and prognosis among Jordanian females. Materials and Methods: In this case-control study, DNA sequencing technique was used to screen SNPs within the untranslated region (UTR) of RAD51 in 206 cases and 185 controls and the resulting data were statistically analyzed using different types of genetic analyses. Patients' clinical and pathological features were obtained from their medical records to perform genotype-phenotype association analysis. Results: Our findings show a significant association between both SNPs rs528590644, rs 1801320 and BC risk $(p=0.016)$. We estimated the correlation between many of BC prognostic factors and BC risk, and we found an association between rs1801321 and age at first menstruation $(p=0.032)$ in addition to a strong correlation between age at $\mathrm{BC}$ diagnosis and rs $1801320(p=0.008)$. Conclusion: RAD51-UTR polymorphisms may be involved in BC development and progression.

Key Words: breast cancer, RAD51-UTR, prognosis, DNA repair pathway.

DOI: 10.32471/exp-oncology.2312-8852.vol-43-no-2.16338

Breast cancer $(\mathrm{BC})$ is a multifactorial disease associated with several factors responsible for its development and progression such as smoking, oxidative stress, pregnancy status, radiation exposure, behavior, diet, and stress [1]. A combination of these environmental and patient-related factors can cause DNA damage and genomic alterations, which may lead to $\mathrm{BC}$ development usually when the DNA repair system is altered. Homologous recombination (HR) proteins play a crucial role in maintaining DNA integrity under many environmental genotoxic factors [2, 3]. Genetic impairments within critical genes that play a specific role in carcinogenesis-related functions may influence $\mathrm{BC}$ development or progression. DNA repairing pathways are the foremost defense mechanisms against genomic instability and DNA damage [4]. Failure of DNA repair system may shift the cell fate to cancer development rather proceeding to apoptosis. For instance, mutations in BRCA1 and BRCA2 are associated with $B C$ occurrence in around $10 \%$ of total cases. Therefore, alterations in other DNA repairing proteins have been proposed to be associated with the development

Submitted: June 29, 2020.

*Correspondence: E-mail: mszoubi@yu.edu.jo

bakshi-h@ulster.ac.uk

hamid.bakshi@gmail.com

Abbreviations used: BC - breast cancer; DSBs - DNA double-

strand breaks; ER - estrogen receptor; HER2 - human epithelial receptor 2; HR - homologous recombination; PCR - polymerase chain reaction; PR - progesterone receptor; SNP - single nucleotide polymorphism; UTR - untranslated region. of many cancers including BC. Mutations, in particular, single nucleotide polymorphisms (SNPs) are the most investigated genetic variants in the human genome to seek a clear vision of the correlation between these variants and malignancies including $\mathrm{BC}[5,6]$.

DNA double-strand breaks (DSBs) occur naturally during cell division or may be caused by environmental exposure [7]. DSB repair mechanism is a fundamental process to maintain the genome integrity and to detect the DSBs that lead to promoting carcinogenesis [8, 9]. Exposing genes that are involved in HR pathway of DSBs repair to the field of study may provide understanding for the biology of cancer [10]. Variants within different genes including ATM, BRIP1, CHEK2, and $X R C C 2$ have been identified as $B C$ inherited risk genetic variants [11-13].

Also, RAD51 has been recently in the spotlight as a key protein that plays a critical role in $\mathrm{HR}$ by mediating the synopsis of the two homologous strands [1416]. RAD51 gene is located on $15 q 15.1$ and comprises nine coding exons [17]; any change in the genetic components of this gene could lead to a significant alteration in the expressed proteins, which may affect the DSBs repair pathway [18].

rs 1801320 is a significant variant located in $5^{\prime}$ untranslated region ( $5^{\prime}$ UTR) of the RAD51 gene and involves the substitution of $\mathrm{G}$ to $\mathrm{C}$ at position 135. It has been suggested that this polymorphism manipulates mRNA stability of RAD51 which in turn affects the DNA repair pathway and subsequently induces tumor formation [19]. In addition to rs1801320, the contribution of RAD51 polymorphisms to $\mathrm{BC}$ has been 
explored [20]. Many epidemiological studies investigated the role of RAD51 in $\mathrm{BC}$ development and progression [17, 21, 22]. Interestingly, these studies have shown disparities in the findings, possibly due to the heterogeneity of the studied cohorts [19, 23-26].

The purpose of this study is to investigate the correlation between SNPs within the $5^{\prime}$-UTR region within $R A D 51$ gene and $\mathrm{BC}$ risk. Furthermore, we aim to clarify the association between a group of clinicopathological features of $\mathrm{BC}$ and the screened polymorphisms in RAD51.

\section{MATERIALS AND METHODS}

Study cohort. In this study, 206 female BC patients in addition to 185 matched healthy individuals were recruited as study subjects from the Jordanian Royal Medical Services hospital. All the participants were randomly selected from Jordanian Arab descent. Ethical approval was obtained from the Intuitional Review Board at Jordan University of Science and Technology with the ethical code number (32/104/2017). Written informed consents were obtained for each volunteer. Descriptive data about patients including demographic, clinical, and pathological information were collected from patients' medical records at Jordanian Royal Medical Services.

DNA extraction. Blood sample $(5 \mathrm{ml})$ was withdrawn from each participant and DNA was extracted using the DNA Purification KitWizard ${ }^{\oplus}$ Genomic (Promega, USA). The extracted DNA was then tested for quality and quantity validation using gel electrophoresis and Nano-Drop ND-1000 UV-Vis Spectrophotometer (BioDrop, UK).

$P C R$ and DNA sequencing. Polymerase chain reaction (PCR) was performed to amplify the $5^{\prime}$-UTR within RAD51 gene using specific sets of primers; F - 5' -AGCTGGGAACTGCAACTCAT-3 and R-5' CGCCTCACACACTCACCTC-3 [27]. Briefly, $3 \mu \mathrm{L}$ of the extracted genomic DNA plus $4 \mu \mathrm{L}$ of primers were added to $12.5 \mu \mathrm{L}$ of $2 \mathrm{X}$ ready to use PCR master mix from New England Biolabs (Taq 2X Master Mix, USA) with nuclease-free water to reach the volume of $25 \mu \mathrm{L}$.

The DNA sequencing was performed as previously published by Al-Eitan et al. [28] using the genetic analyzer (3130x1, Applied Biosystems, USA) according to the BigDyeTerminator v3.1 Cycle Sequencing Kit (Applied Biosystems, USA). Subsequently, the chromatograms of the sequenced DNA were visualized using Chromas Pro software v.1 (USA) and compared to a reference sequence (EnsembI ID: ENSG00000178568) using Ensembl genome browser (http://www.ensembl.org/index. html).

Statistical analysis. Hardy - Weinberg equilibrium equation (Court lab - HW calculator) was used to calculate the genotypic and allelic frequencies. The genetic association was estimated using Pearson's chi-square test. In addition, genetic association using different genetic models was performed using SNPSTAT software (version 2.11 of Bioconductor). Pearson's chi-square and ANOVA tests were also used to estimate the phenotype-genotype correlation. In this study, $p$-value was considered as statistically significant only if less than 0.05 . The Statistical Package for the Social Sciences (SPSS), version 25.0 (SPSS, Inc., USA) was used to conduct the statistical analysis.

\section{RESULTS}

Candidate SNPS of RAD51 and their association with BC. Table 1 illustrates the selected polymorphisms within RAD51-UTR. In this study, four out of the seven SNPs that have been screened were polymorphic. The genotype and allele frequencies for the screened polymorphisms of RAD51 are also summarized in Table 1. Remarkably, the variant allele (C) of rs528590644 was not detected among patients, while it accounted for $1 \%$ among controls and the minor allele $(G)$ of rs530836900 was not observed among controls except for individual cases. Furthermore, the homozygous variant allele (TT) distribution among cases $(26.3 \%)$ was significantly higher than among controls (14.3\%) of rs 1801320 . Our findings revealed that both polymorphisms rs528590644 and rs 1801320 were associated with BC with the same $p$ value $(p=0.016)$. However, neither rs530836900 nor rs 1801321 were in correlation with BC in this study (Table 1).

In addition, a genetic association test using different genetic models was performed to clarify the relationship between RAD51 polymorphisms and BC. As Table 2 shows, only rs 1801320 and rs 1801321 were applicable for this test. Our findings revealed that none of the investigated models showed significant association with $\mathrm{BC}$ except for the co-dominant and recessive models of $r s 1801320(p=0.015$ and 0.0038 , respectively) (Table 2).

Haplotype analysis. Haplotypes resulted from RAD51-UTR polymorphisms (rs1801321, rs1801320, rs530836900, and rs528590644) are demonstrated in Table 3. The table shows haplotype variant frequencies in case and control. The haplotype analysis in this study revealed a significant association between GTCA haplotype and BC risk, $p=0.005$ (Table 3).

Genotype-phenotype analysis. In this study group of clinical and pathological features of $B C$ being characterized and tested for correlation with RAD51UTR polymorphisms, most of these features are prognostic and predictive factors for BC. Table 4 illustrates these parameters and their association with RAD51 SNPs. We found an association between rs1801321 and age at first menstruation $(p=0.032)$, in addition to a strong correlation between age at $\mathrm{BC}$ diagnosis and rs1801320 $(p=0.008)$. However, there was no relationship between rs530836900 and any of the investigated clinical factors (Table 4).

Moreover, Table 4 summarizes the pathological parameters of $B C$ and their relationship with RAD51-UTR variants. Common and critical factors for BC prognosis such as progesterone (PR) and estrogen receptor (ER) status and human epithelial 
Table 1. Genetic association between RAD51-UTR candidate SNPS and BC

\begin{tabular}{|c|c|c|c|c|c|c|}
\hline Gene & SNPID & Allele/Genotype & Cases (206) & Controls (185) & Chi-square & $p$-value \\
\hline \multirow{18}{*}{ RAD51-UTR } & & $\mathrm{A}$ & $424(100 \%)$ & $363(99 \%)$ & 5.797 & $0.016^{\star}$ \\
\hline & \multirow{2}{*}{ rs528590644 } & C & 0 & $5(1 \%)$ & & \\
\hline & & AA & $212(100 \%)$ & $179(97.3 \%)$ & 5.835 & $0.016^{\star}$ \\
\hline & \multirow{5}{*}{ rs530836900 } & $A C$ & 0 & $5(2.7 \%)$ & & \\
\hline & & C & 396 (99.5\%) & $366(100 \%)$ & 1.844 & 0.174 \\
\hline & & G & $2(0.5 \%)$ & 0 & & \\
\hline & & CG & $2(1 \%)$ & 0 & 1.84 & 0.398 \\
\hline & & CC & 198 (99\%) & $183(100 \%$ & & \\
\hline & & C & 54 (13.4\%) & 45 (12.4\%) & 0.148 & 0.700 \\
\hline & \multirow{4}{*}{ rs 1801321} & G & 350 (86.6\%) & $317(87.6 \%)$ & & \\
\hline & & CC & $3(1.5 \%)$ & $4(2.2 \%)$ & & \\
\hline & & CG & $48(23.8 \%)$ & $37(20.5 \%)$ & 0.833 & 0.659 \\
\hline & & GG & 151 (74.7\%) & 140 (77.3\%) & & \\
\hline & \multirow{5}{*}{ rs1801320 } & $\mathrm{T}$ & 189 (46.8\%) & $139(38.4 \%)$ & 5.482 & $0.019^{*}$ \\
\hline & & G & 215 (53.2\%) & 223 (61.6\%) & & \\
\hline & & TT & $53(26.3 \%)$ & $26(14.3 \%)$ & & \\
\hline & & TG & $83(41 \%)$ & 87 (48.1\%) & 8.225 & $0.016^{*}$ \\
\hline & & GG & $66(32.7 \%)$ & $68(37.6 \%)$ & & \\
\hline
\end{tabular}

Note:*significant difference.

Table 2. Genetic association between RAD51-UTR polymorphisms and BC using different genetic models

\begin{tabular}{cllc}
\hline Gene & SNP ID & \multicolumn{1}{c}{ Category test } & $p$-value* \\
\hline & rs1801320 & Co-dominant: common Hz (GG) vs Het (GT) vs Rare Hz(TT) & $0.015^{\star}$ \\
& & Dominant; Common Hz (GG) vs Het and Rare Hz (GT+TT) & 0.320 \\
& & Recessive: Common Hz and Het (GG+GT) vs Rare Hz (TT) & $0.003^{*}$ \\
RAD51-UTR & & Over dominant: Common Hz and Rare Hz (GG+TT) vs Het (GT) & 0.170 \\
& & Co-dominant: common Hz (GG) vs Het (GC) vs Rare Hz(CC) & 0.660 \\
& & Dominant; Common Hz (GG) vs Het and Rare Hz (GC+CC) & 0.550 \\
& & Recessive: Common Hz and Het (GG+GC) vs Rare Hz (CC) & 0.600 \\
\hline
\end{tabular}

Note: ${ }^{\star}$ significant difference.

Table 3. Haplotype analysis of RAD51-UTR polymorphisms

\begin{tabular}{lcccc}
$\begin{array}{c}\text { Haplotype RAD51-UTR (rs1801321, rs1801320, } \\
\text { rs530836900 and rs528590644) }\end{array}$ & Frequency of block & $\begin{array}{c}\text { Frequency ratio (case: con- } \\
\text { trol), } \%\end{array}$ & Odd ratio (95\%) Cl & p-value \\
\hline GGCA & 0.4462 & $0.3976: 0.5021$ & 1.0 & $\mathrm{NA}$ \\
GTCA & 0.4184 & $0.4641: 0.3659$ & $0.65(0.48-0.88)$ & $0.0058^{*}$ \\
CGCA & 0.1215 & $0.1333: 0.1069$ & $0.63(0.39-1.03)$ & 0.067 \\
Global haplotype association $p$-value: 0.0067 & & & & \\
\hline
\end{tabular}

Note: ${ }^{*}$ significant difference.

Table 4. Association of RAD51-UTR SNPs with clinicopathological characteristics of $\mathrm{BC}$ patients

\begin{tabular}{|c|c|c|c|}
\hline Clinical characteristics & $\begin{array}{c}\text { rs } 1801321 \\
\text { (GG vs CG vs CC) } \\
p \text {-value }\end{array}$ & $\begin{array}{c}\text { rs } 1801320 \\
\text { (TT vs TG vs GG) } \\
p \text {-value }\end{array}$ & $\begin{array}{c}\text { rs530836900 } \\
\text { (CC vs CG) } \\
p \text {-value }\end{array}$ \\
\hline Body mass index ${ }^{\star \star}$ & 0.621 & 0.848 & 0.408 \\
\hline First pregnancy (age) ${ }^{\star \star}$ & 0.910 & 0.579 & 0.520 \\
\hline Age at BC diagnosis** & 0.645 & $0.008^{\star \star \star}$ & 0.487 \\
\hline Allergy* & 0.498 & 0.501 & 0.098 \\
\hline Age at first menstruation** & $0.032^{\star \star \star}$ & 0.722 & 0.516 \\
\hline Breastfeeding status* & 0.375 & 0.833 & 0.473 \\
\hline Age at menopause ${ }^{\star \star}$ & 0.261 & 0.837 & 0.476 \\
\hline Family history* & 0.169 & 0.577 & 0.482 \\
\hline Co-morbidity* & 0.910 & 0.335 & 0.291 \\
\hline Smoking* & 0.653 & 0.512 & 0.533 \\
\hline \multicolumn{4}{|l|}{ Pathological characteristics } \\
\hline Progesterone receptor* & 0.884 & 0.051 & 0.311 \\
\hline Estrogen receptor ${ }^{\star}$ & 0.923 & 0.240 & 0.587 \\
\hline HER2* ${ }^{*}$ & 0.964 & 0.499 & 0.986 \\
\hline IHC profile (L.A vs L.B vs T.N) & 0.931 & 0.413 & NA \\
\hline Tumor differentiation grade* & 0.871 & 0.083 & 0.461 \\
\hline Axillary lymph nodes* & 0.245 & 0.143 & 0.306 \\
\hline Tumor stage* & 0.860 & 0.509 & 0.770 \\
\hline Histology classification* & 0.669 & 0.906 & 0.370 \\
\hline Tumor size ${ }^{\star \star}$ & 0.236 & 0.919 & 0.402 \\
\hline Lymph node involvement* & 0.298 & 0.694 & 0.646 \\
\hline
\end{tabular}

Note: * genotype-phenotype association $p$-value using Pearson Chi-squared test; ${ }^{* *}$ genotype-phenotype association $p$-value using ANOVA test. L.A: luminal A; L.B: luminal B; T.N: triple negative; ${ }^{\star \star \star}$ significant difference.

receptor 2 (HER2) were included. In this current study, no association was disclosed between any of these pathological factors and the investigated polymorphisms of RAD51-UTR.

The heterogeneity of molecular markers (PR, ER, and HER2) which are known as immunohistochemistry
(IHC) profile was also studied. Considering that data was available for only 124 patients, Table 4 shows three different types of $B C$ according to IHC profiles: luminal $\mathrm{A}$; $\mathrm{ER}(+)$ and /or $\mathrm{PR}(+)$ plus HER(-), luminal $\mathrm{B}: \mathrm{ER}(+)$ and /or $\mathrm{PR}(+)$ plus $\mathrm{HER}(+)$ and T.N: triple negative $\mathrm{ER}(-)$ and $\mathrm{PR}(-)$ plus HER(-). However, we did not 
detect any association between $\mathrm{BC}$ types and RAD51UTR polymorphisms (Table 4).

\section{DISCUSSION}

A malfunction in DNA repair mechanics is the starting point for cancer development [29]. DSB is a reliable repair system responsible for genome integrity and stability [30]. Correspondingly, genetic alteration within a functional gene that plays a key role in DSB repair pathway may lead to cancer development including $\mathrm{BC}$ [31]. RAD51 is one of the important genes that participate in the DSB repair system [32-35].

In this study, four polymorphic SNPs have been screened in BC female patients and matched healthy subjects. We investigated the association between RAD51-UTR polymorphisms and $\mathrm{BC}$ as well as the clinical and pathological prognosis parameters.

Genetic association analyses in this study indicated a significant association between both polymorphisms (rs528590644, rs1801320) and $\mathrm{BC}$ risk while the other two SNPs were not in correlation with $\mathrm{BC}$. Our findings showed that the distribution of rs528590644 variant allele (C) was only distributed among controls but not among cases in contrast to the common allele $(A)$ distribution. In light of these results, we propose the (A) allele of rs528590644 within RAD51-UTR as an increased risk variant for $\mathrm{BC}$ among Jordanian females. Concerning rs 1801320 , we suggest that both variant allele (T) and homozygous variant (TT) genotype are implicated in BC development and progression in Jordanian women. Haplotype analysis was conducted in this study to show the combined effects of RAD51-UTR on BC risk. Significantly, we propose that GTCA haplotype is linked with BC susceptibility.
Furthermore, the influence of RAD51-UTR polymorphisms on BC prognosis was explored. In this work, we detect an association between rs1801321 and age at first menstruation in addition to a correlation between age at BC diagnosis and rs 1801320 . Therefore, we propose that $R A D 51$ variants may interfere with $B C$ prognosis. However, we did not find any connection between RAD51 polymorphisms and the investigated pathological factors.

Several studies investigated candidate polymorphisms within the RAD51 gene and how they could be correlated to BC development and progression [24, 36-38]. However, inconsistent findings among ethnic groups and within the same population have been revealed. In accordance to this study, Sekhar et al. [39] stated that homozygous substitution (CC) of $135 \mathrm{G}>\mathrm{C}$ polymorphism within RAD51 increases the risk of BC significantly. In contrast, Korak et al. [19], Sliwinski et al. [40], and Synoweic et al. [41] did not find any association between $B C$ risk and RAD51 135G $>C$ polymorphism. Le Calvez-Kelm et al. [26] also screened RAD51 for rare variants in 1.330 early-onset $B C$ cases in addition to 1.123 controls and reported no significant disease-related genetic variant.

Despite the independent role of RAD51 in tumorigenesis, it has been known to interact with other genes such as $B R C A 1 / 2$ for HR repair. In this regard, the impact of $R A D 51$ variants among $B C B R C A 1 / 2$ mutation carriers on $B C$ risk has been also explored, both studies by Lose et al. [17] and Rapakko et al. [22] reported no association between $B R C A 1$ and $B R C A 2$-negative $B C$ and RAD51 variation. Nevertheless, RAD51 has been found to be involved in the triple negative $B C$ me-

(a)

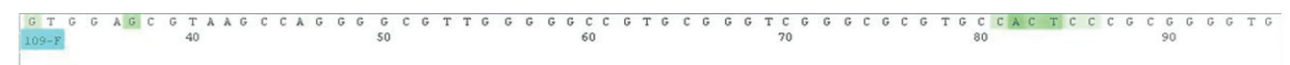

(b)

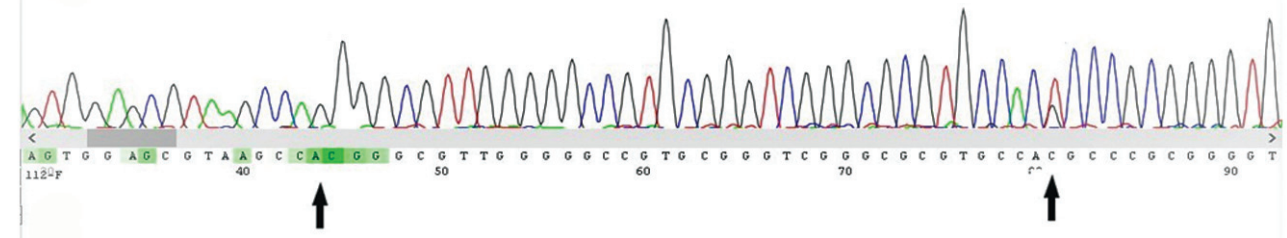

(c)
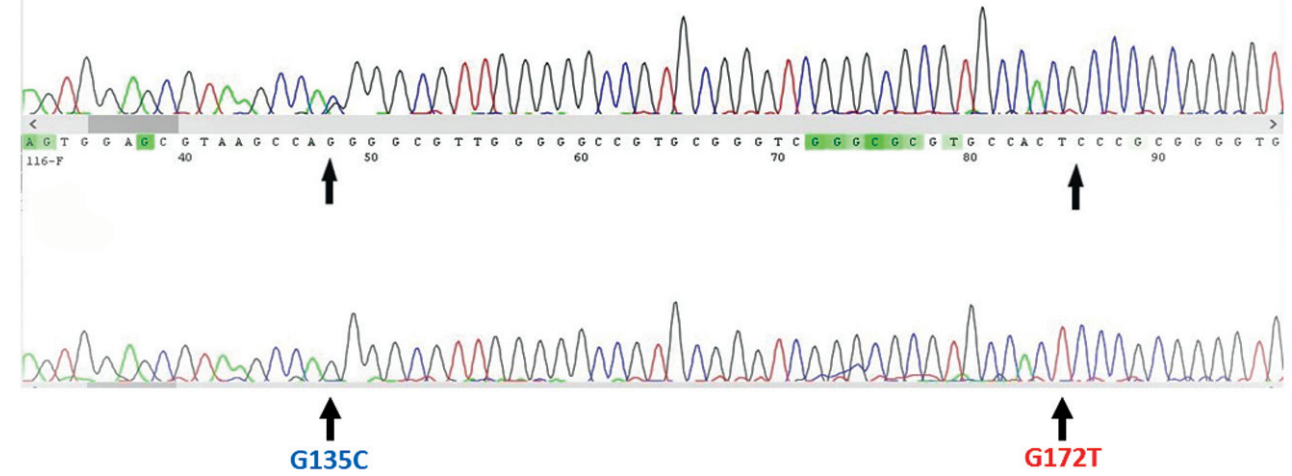

Figure. A representative chromatogram of the 5'UTR region in the RAD51 gene: a - representing sample with GG genotype for G135C variant and GT genotype for G172T variant; $b$ - representing sample with GC genotype for G135C variant and GG genotype for the G172T variant; c - representing sample with GG genotype for the G135C variant and TT genotype for the G172T variant 
tastasis [42, 43]. And RAD51 targeting have shown a promising $B C$ treatment option $[44,45]$.

In conclusion, we propose that genetic alteration of RAD51 may influence its vital function and correspondingly influence tumor formation including BC. Moreover, RAD51 polymorphisms may be involved in poor prognosis of BC. Comprehensive studies including protein and mRNA research are needed to reveal the precise role of $R A D 51$ rare variants on $\mathrm{BC}$ progression and development for better understanding of $\mathrm{BC}$ biology that may lead to new therapeutic regimens which in turn increase the survival rates worldwide.

\section{CONFLICT OF INTEREST DISCLOSURES}

All authors declare no conflict of interest.

\section{FUNDING}

This work was funded by the Deanship of Scientific Research and Graduate Studies at Yarmouk University (Grant № 12/2015).

\section{ACKNOWLEDGEMENT}

This work could not be completed without the help of our colleagues and technicians, specifically Miss Manal Abu Al Arja. We would like to express our thanks to Dr. Greg Eaton - Rowan University for his technical assistant.

\section{REFERENCES}

1. Ferlay J, Colombet M, Soerjomataram I, et al. Cancer incidence and mortality patterns in Europe: Estimates for 40 countries and 25 major cancers in 2018. Eur J Cancer 2018; 103: $356-87$.

2. Shiovitz S, Korde LA. Genetics of breast cancer: a topic in evolution. Ann Oncol 2015; 26: 1291-9.

3. Stratton MR, Rahman N. The emerging landscape of breast cancer susceptibility. Nat Genet 2008; 40: 17 .

4. King M-C, Marks JH, Mandell JB. Breast and ovarian cancer risks due to inherited mutations in BRCA1 and BRCA2. Science 2003; 302: 643-6.

5. Cuzick J, Brentnall A, Dowsett M. Dowsett. SNPs for breast cancer risk assessment. Oncotarget 2017; 8: 99211.

6. Easton DF, Pharoah PD, Antoniou AC, et al. Gene-panel sequencing and the prediction of breast-cancer risk. N Engl J Med 2015; 372: 2243-57.

7. Vamvakas S, Vock EH, Lutz WK. On the role of DNA double-strand breaks in toxicity and carcinogenesis. Crit Rev Toxicol 1997; 27: 155-74.

8. Haber JE. Partners and pathways: repairing a doublestrand break. Trends Genet 2000; 16: 259-64.

9. Gullotta F, De Marinis E, Ascenzi P, et al. Targeting the DNA double strand breaks repair for cancer therapy. Curr Med Chem 2010; 17: 2017-48

10. Scott RJ. DNA double strand break repair and its association with inherited predispositions to breast cancer. Hered Cancer Clin Pract 2004; 2: 37.

11. Tavtigian SV, Oefner PJ, Babikyan D, et al. Rare, evolutionarily unlikely missense substitutions in ATM confer increased risk of breast cancer. Am J Hum Genet 2009; 85: $427-46$

12. Seal S, Thompson D, Renwick A, et al. Truncating mutations in the Fanconi anemia J gene BRIP1 are lowpenetrance breast cancer susceptibility alleles. Nat Genet 2006; 38: 1239-41
13. Le Calvez-Kelm F, Lesueur F, Damiola F, et al. Rare, evolutionarily unlikely missense substitutions in CHEK2 contribute to breast cancer susceptibility: results from a breast cancer family registry case-control mutation-screening study. Breast Cancer Res 2011; 13: R6.

14. Lambert S, Lopez BS. Characterization of mammalian RAD51 double strand break repair using non-lethal dominantnegative forms. EMBO J 2000; 19: 3090-9.

15. Baumann P, West SC. Role of the human RAD51 protein in homologous recombination and double-stranded-break repair. Trends Biochem Sci 1998; 23: 247-51.

16. Kim PM, Allen C, Wagener BM, et al. Overexpression of human RAD51 and RAD52 reduces double-strand breakinduced homologous recombination in mammalian cells. Nucleic Acids Res 2001; 29: 4352-60.

17. Lose F, Lovelock P, Chenevix-Trench G, et al. Variation in the RAD51 gene and familial breast cancer. Breast Cancer Res 2006; 8: R26.

18. Hiramoto T, Nakanishi T, Sumiyoshi T, et al. Mutations of a novel human RAD54 homologue, RAD54B, in primary cancer. Oncogene 1999; 18: 3422-6.

19. Korak T, Ergul E, Uren N, et al. RAD51 (rs1801320) gene polymorphism and breast cancer risk in Turkish population. Int J Clin Exp Pathol 2017; 10: 2181-6.

20. Krivokuca AM, Malisic EJ, Dobricic JD, et al. RAD51 135G $>$ C and TP53 Arg72Pro polymorphisms and susceptibility to breast cancer in Serbian women. Fam Cancer 2014; 13: 173-80.

21. Kato M, Yano K-i, Matsuo F, et al. Identification of Rad51 alteration in patients with bilateral breast cancer. J Hum Genet 2000; 45: 133-7.

22. Rapakko K, Heikkinen K, Karppinen S-M, et al. Screening for RAD51 and BRCA2 BRC repeat mutations in breast and ovarian cancer families. Cancer Lett 2006; 236: $142-7$.

23. Smolarz B, Michalska MM, Samulak D, et al. Polymorphism of DNA repair genes in breast cancer. Oncotarget 2019; 10: 527.

24. Grešner P, Jabłońska E, Gromadzińska J. Rad51 paralogs and the risk of unselected breast cancer: A case-control study. PloS One 2020; 15: e0226976.

25. Parvin S, Islam MS, Al-Mamun MMA, et al. Association of BRCA1, BRCA2, RAD51, and HER2 gene polymorphisms with the breast cancer risk in the Bangladeshi population. Breast Cancer 2017; 24: 229-37.

26. Le Calvez-Kelm F, Oliver J, Damiola F, et al. RAD51 and breast cancer susceptibility: no evidence for rare variant association in the Breast Cancer Family Registry study. PLoS One 2012; 7: e52374.

27. Al-Zoubi MS, Mazzanti CM, Zavaglia K, et al. Homozygous T172T and Heterozygous G135C variants of homologous recombination repairing protein RAD51 are related to sporadic breast cancer susceptibility. Biochem Genet 2016; 54: 83-94.

28. Bae JS, Pasaje CFA, Park B-L, et al. Genetic association analysis of ERBB4 polymorphisms with the risk of schizophrenia and SPEM abnormality in a Korean population. Brain Res 2012; 1466: 146-51.

29. Nikolaev A, Yang ES. The impact of DNA repair pathways in cancer biology and therapy. Cancers 2017; 19: 126.

30. Taylor EM, Lehmann AR. Conservation of eukaryotic DNA repair mechanisms. Int J Radiat Biol 1998; 74: 277-86.

31. Meek DW. Tumour suppression by p53: a role for the DNA damage response? Nat Rev Cancer 2009; 9: 714-23. 
32. Bhattacharya S, Srinivasan $\mathrm{K}$, Abdisalaam S, et al. RAD51 interconnects between DNA replication, DNA repair and immunity. Nucleic Acids Res 2017; 45: 4590-605.

33. Benson FE, Baumann P, West SC. Synergistic actions of Rad51 and Rad52 in recombination and DNA repair. Nature 1998; 391: 401-4.

34. Tambini CE, Spink KG, Ross CJ, et al. The importance of XRCC2 in RAD51-related DNA damage repair. DNA repair 2010; 9: 517-25.

35. Lord CJ, Ashworth A. RAD51, BRCA2 and DNA repair: a partial resolution. Nat Struct Mol Biol 2007; 14: 461-2.

36. Blasiak J, Przybyłowska K, Czechowska A, et al. Analysis of the G/C polymorphism in the $5^{\prime}$-untranslated region of the RAD51 gene in breast cancer. Acta Biochim Pol 2003; 50: 249-53.

37. Krupa R, Synowiec E, Pawlowska E, et al. Polymorphism of the homologous recombination repair genes RAD51 and XRCC3 in breast cancer. Exp Mol Pathol 2009; 87: 32-5.

38. Gao L-B, Pan X-M, Li L-J, et al. RAD51 135G/C polymorphism and breast cancer risk: a meta-analysis from 21 studies. Breast Cancer Res 2011; 125: 827-35.

39. Sekhar D, Pooja S, Kumar S, et al. RAD51 135G> $\mathrm{C}$ substitution increases breast cancer risk in an ethnic-specific manner: a meta-analysis on 21236 cases and 19407 controls. Sci Rep 2015; 5: 1-10.

40. Sliwinski T, Krupa R, Majsterek I, et al. Polymorphisms of the BRCA2 and RAD51 genes in breast cancer. Breast Cancer Res Treat 2005; 94: 105-9.

41. Synowiec E, Stefanska J, Morawiec Z, et al. Association between DNA damage, DNA repair genes variability and clinical characteristics in breast cancer patients. Mutat Res 2008; 648: 65-72.

42. Wiegmans AP, Al-Ejeh F, Chee N, et al. Rad51 supports triple negative breast cancer metastasis. Oncotarget 2014; 5: 3261.

43. Liu Y, Burness ML, Martin-Trevino R, et al. RAD51 mediates resistance of cancer stem cells to PARP inhibition in triple-negative breast cancer. Clin Cancer Res 2017; 23: 514-22.

44. Gasparini P, Lovat F, Fassan M, Casadei L, et al. Protective role of miR-155 in breast cancer through RAD51 targeting impairs homologous recombination after irradiation. Proc Natl Acad Sci USA 2014; 111: 4536-41.

45. Ward A, Khanna KK, Wiegmans AP. Targeting homologous recombination, new pre-clinical and clinical therapeutic combinations inhibiting RAD51. Cancer Treat Rev 2015; 41: $35-45$.

\section{ГЕНЕТИЧНИЙ ПОЛІМОРФІЗМ ГАПЛОТИПУ RAD51-UTR TA CХИЛЬНІСТЬ ДО РАКУ МОЛОЧНОЇ ЗАЛОЗИ У ЖІНОК З ЙОРДАНСЬКОї популяції}

М.С. Аль Зубі ${ }^{1, ~ *, ~ Л . Н . ~ А л ь-Е и ̆ т а н ~}{ }^{2}$, Д.М. Рабаба ${ }^{1}$, К. АльБетейнех ${ }^{1}$, Р. Фарзанд ${ }^{3}$, Г.Е. Квін4, М.М. Тамбувала ${ }^{4}$, Х.A. Бакші , * $^{\text {* }}$

${ }^{1}$ Університет Ярмука, Ірбід 21163, Йорданія

${ }^{2}$ Йорданський університет науки і технологій, Ірбід 22110, Йорданія

${ }^{3}$ Університет Хаддерсфілда, Квінсгейт, HD12ZD, Сполучене Королівство

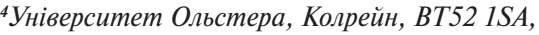
Сполучене Королівство

Стан питання: Генетична схильність до раку молочної залози (РМЗ) широко вивчалася для досягнення більш глибокого розуміння біології РМЗ. Пошук генів-кандидатів для скринінгу різних генетичних варіантів, таких як ген RAD51, який відіграє важливу роль у репарації ДНК, включаючи систему репарації дволанцюгових розривів, $є$ важливим завданням. Мета: Дослідити кілька однонуклеотидних поліморфізмів (SNP) у гені RAD51-UTR і виявити їх взаємозв'язок з ризиком розвитку РМЗ і прогнозом серед йорданських жінок. Матеріали та методи. У цьому дослідженні «випадок-контроль» метод секвенування ДНК використовувався для скринінгу SNP в нетрансльованій ділянці (UTR) RAD51 у 206 випадках і 185 контрольних зразках. Отримані дані були статистично проаналізовані з використанням різних методів генетичного аналізу. IHформація про клінічні та патологічні характеристики пацієнтів була отримана з їх медичних карт і використана для проведення аналізу асоціації генотип-фенотип. Результати: Отримані результати вказують на значний зв'язок між обома SNP rs528590644, rs1801320 і ризиком розвитку РМЗ $(p=0,016)$. Ми оцінили кореляцію між багатьма прогностичними факторами РМЗ і ризиком РМЗ і виявили зв'язок між rs1801321 і віком першої менструації ( $p=0,032)$, а також сильну кореляцію між віком на момент встановлення діагнозу i rs $1801320(p=0,008)$. Висновок: Поліморфізми RAD51-UTR можуть відігравати роль у розвитку та прогресії РМЗ.

Ключові слова: рак молочної залози, RAD51-UTR, прогноз, шляхи репарації ДНК. 